\title{
O IMPOSSÍVEL RETORNO
}

Walnice Nogueira Galvão

"Meu tio o iauaretê", de Guimarães Rosa narra a estória de um mestiço de índia com branco e seu destino exemplar. Agregado do fazendeiro que o envia para desonçar vizinho os confins do sertão, vai gradativamente rejeitando o civilizado e aceitando o animal. Acaba preferindo onças a homens, acaba virando onça e matando homens.

De maneira extraordinária como Guimarães Rosa montou seu texto, já falou Haroldo de Campos, em "A linguagem do Iauaretê" (1) Misturando português com tupi mais onomatopéias de ruídos e rugidos, a própria personagem constrói o enredo numa fala ininterrupta, insulta o conto nos limites de uma só noite. Assim o vemos, recebendo como leitores sua fala emitida para outra personagem que nunca interfere e com que ele conversa, transformar-se em onça diante de nossos olhos e atacar seu interlocutor, sendo morto a tiros de revólver.

Se o matador de onças com elas se identifica e se torna matador de homens - e está coberto de razões, a rejeição do mundo civilizado, domínio do cozido, é inversamente acompanhada pela volta ao mundo da natureza, domínio do cru. Na linha de separação entre ambos, posta-se o fogo. Nada mais razoável, portanto, que o fogo, fundação da cultura, marco de passagem do cru ao cozido, tenha função predominantemente neste conto.

Deva-se a informação anterior, deva-se a perspicaz intuição, este conto se encontra fundado, na mesma linha de regressão, num mito de origem do fogo. No mito, o fogo era da onça e os homens o roubaram dela. O conto devolve, ou tenta devolver, o seu a seu dono.

(1). - CAMPOS, Haroldo de, "A linguagem do Iaua:etê", em Metalinguagem, 1970, Petrópolis, 2a ed. Ed. Vozes; com Augusto de Campos e Pedro Xisto, em Guimarães Rosa em Três Dimensões, 1970, São Paulo, Comselho Estadual de Cultura; republicação de artigo anterior no Suplemento Literário d'O Estado de São Paulo, 1962. 
Os estudiosos já apontaram a notável onipresença dessa onça mítica pelas Américas, entre povos muito diferentes, de origens diferentes e pertencentes a grupos lingüísticos diferentes (2). O culto do chamado "jaguar solar" aponta para a dimensão mais que brasileira, também americana, mas sobretudo latino-americana, do conto. Conhecem-se, em alguns lugares mais, em outros menos, evidências desse culto em toda parte, desde um pouco ao norte do México até o extremo sul do continente.

$\mathrm{Na}$ própria região do atual México, entre a infinidade de povos que ali se misturaram durante milênios, uma das culturas mais antigas é a do povo-jaguar, os "Olmecas" da Fase La Venta. As representações em pedra mostram figuras humanas cujo rosto mistura aos humanos os traços felinos: boca arreganhada, caninos salientes, olhos repuxados, nariz achatado e sobrancelhas "chamejantes" Para esse povo, o jaguar é seu ancestral; nasceram da cópula entre uma mulher e um jaguar, de que resultou um beb仓̂-jaguar (3).

Os Aztecas devem ter-se apropriado de cultos muito mais antigos, misturando-os aos seus, já que são apenas a última das muitas levas de migrações Nahuatl vindas do norte; e foi tão tarde quanto 1370 que se instalaram no lago de Texcoco, onde fica a atual cidade do México, e fundaram Tenochtitlan, capital do poderoso império. Sua concepção das quatro criações e destruições do mundo atribui a quarta delas aos tigres. Nesse passado remoto, a intervenção, sempre benéfica, do deus Quetzalcóatl, impediu a extinção da humanidade e salvou alguns homens, que se transformaram em gigantes; destruídos estes, o mundo ficou despovoado e sem o Sol, que se extinguia no cataclisma cósmico. Para fazer renascer o sol, Quetzalcóatl sacrificou-se, derramando seu sangue sobre ossos, dos quais nasceram os homens. Por isso, o sacrifício de sangue deve ser constantemente renovado, para que o Sol, e com ele a vegetação, a água e os homens, não pereçam.

Outras versões dos povos mexicas (4) sublinham a rivalidade entre os dois deuses principais, Quetzalcóatl doador de bens naturais e culturais, e Tezcatlipoca, maligno, ao mesmo tempo o tigre, cujo pe-

(2). - Para um estudo a respeito, v. Sílvia Maria Schmuziger de Carvalho, Mito e Ideologia - O Mecanismo de Formação e Difusão dos Mitos na Área Cultural do Alto Rio Negro, 1973, tese de doutoramento, ed. mimeografada, FFCL, de Franca, especialmente caps. VII e VIII. A sair, pela Editora Ática, com o título de Jurupari - Estudos de Mitologia Brasileira.

(3). - HABERLAND, Wolfgang, Culturas de América Indígena - Mesoamémerica y América Central, 1974, México, Fondo de Cultura Economica.

(4). - O esplêndido Mureu de Antropologia do México não dá aos Aztecas uma sala separada, mas os inclui junto com outros povos com que se misturaram no Vale do México numa mesma Sala Mexica. 
lame mosqueado reflete o céu noturno com suas estrelas, a constelação da Ursa Maior e o Sol. Num dos lances da teomaquia, Quetzalcóatl derrubou o sol Tezcatlipoca do céu, com terríveis consequiências: transformado em tigre, o Sol comeu tudo o que havia e o mundo ficou sem sol - a data mítica no calendário azteca é o dia "4 Tigre" —,o que obrigou Quetzalcóatl a tornar-se sol até que o tigre por sua vez o derrubou do céu, havendo outra catástrofe (5).

$\mathrm{Na}$ época mais conhecida da conquista espanhola, quando em 1521 foi arrazada a cidade inteira de Tenochtitlan-Tlateloco, com cerca de 250.000 habitantes e portanto uma das maiores do mundo de então, a onça pintada aparecia na casta guerreira dominante azteca, dividida em cavalheiros-águia e cavalheiros-jaguar. Nas artes plásticas estes aparecem como homens vestidos inteirinhos com uma pele de onça, apenas o rosto surgindo entre as fauces do animal. $O$ importantíssimo e perigoso deus Tezcatlipoca, multiforme, enquanto inventor do fogo, é às vezes confundido com outros deuses protetores do fogo. E uma de suas aparências é como Tepeyelohtli, "o coração do cerro" (de tepetl, cerro ou monte, e yólotl ou yolotli, coração) (6), que aparece disfarçado de tigre, vestido com a pele dele, tal como os cavalheiros-tigre, saindo da pele suas extremidades humanas, exceto o pé que perdeu na luta com Quetzalcóatl e foi substituído por um "espelho fumegante"

No Popol Vuh, único códice maia, que escapou à queima deliberada praticada pelos conquistadores, o tigre é um dos animais deificados que são transformados em pedra ao primeiro surgimento do sol. A bela linguagem esotérica, na tradução espanhola, segue nesta reflexão: "Tal vez no estaríamos vivos hoy día a causa de los animales voraces, el león, el tigre, la culebra, el cantil y el duendes; quizás no existiría ahora nuestra gloria si los primeros animales no se hubieran vuelto piedra por obra del sol" (7). O fogo é ali concedido pelo deus Tohil, criador do fogo, aos quatro primeiros homens-heróis civilizadores, feitos de massa de milho pelos deuses. Outros homens também o querendo, Tohil exigiu em troca o sacrifício de sangue, seja na forma da extração com espinhos - das orelhas e dos cotovelos, segundo - Popol Vuh, mas também de outras partes do corpo segundo diversas fontes - seja na forma tão difundida em todas as culturas mesoamericanas da oferenda do coração arrancado do peito. O sangue re-

(5). - CASO, Alfonso, El Pueblo del Sol, 1971, México, 2a ed., Fondo de Cultura Economica.

(6). - CABRERA, Luís, Dicionario de Aztequismos, 1975, México, 2a ed., Ed. Oasis.

(7) - Popol Vuh, trad. Adrián Recinos, 1975, México, 10 ed., Fondo de Cultura Economica. 
pete o sacrifício de Quetzalcóatl - e garante a subsistência da ordem cósmica.

Por outro lado, uma belíssima estela maia (8) representa um jaguar pintado, as manchas maiores e menores caprichosamente excavadas na superfície da pedra, com um dos braços estendido pata um coração humano.

Ainda no Popol Vuh, os quatro heróis civilizadores começam a roubar homens de outras tribos para sacrificálos aos deuses. Os que davam pela falta só encontravam o sangue vertido no caminho e a cabeça; no mais, só rastros de tigre.

O culto do jaguar "Olmeca" tem similaridades importantes também nos Andes, em sua zona central, particularmente na cultura Chavín, em Tiahuanaco e San Angustín, irradicando de um foco onde hoje ficam Bolívia e Peru, foi império incaico. Talvez se trate de culturas-mães muito primitivas, que nesse e em outros traços se aparentam aos "Olmecas" (9).

A onça mítica às vezes ressurge de maneira inesperada. Danças populares com máscaras de onça são muito correntes hoje-em-dia entre os índios mexicanos. Mas quem esperaria encontrá-la nas cavalhadas brasileiras contemporâneas? Pois lá está ela, elemento integrante das festas de cristãos e mouros, aparentemente inexplicável e insólita - pois o que tem a ver a onça americana com o folclore ibérico? mas perfeitamente compreensível após a análise de Carlos Rodrigues Brandão da festa em Goiás. (10) O autor mostra como o conflito ritualizado entre cristãos e mouros, que se dá no mundo humano, é reconciliado no nível sobrenatural, sendo indispensável para essa reconciliação que o "espião mouro", usando pele e máscara de onça e imitando seus modos, como representante do mundo da nalureza, seja inicialmente eliminado, e a tiros de arma de fogo.

Dentre a fartura de mitos indígenas brasileiros referentes à onça senhor do fogo, escolho de propósito, como se verá, a versão que Horace Banner publicou em seu trabalho "Mitos dos índios Kayapó, (11intitulado "O fogo da onça"; é o que segue.

(8) . - Exposta no Museu de Antropologia do México, Sala Maia.

(9). - COVARRUBIAS, Miguel, The Eagle, The Jaguar and the Serpent, 1967, New Yokk, 2a ed., Alfred Knopf Inc.

(10) - BRANDÃO, Carlos Rodrigues, Cavalhadas de Pirenópolis, 1973, Goiânia, Ed. Oriente.

(11). - BANNER, Horace, "Mitos dos índios Kayapó", Revista de Antropologia, Vol. 5, $\mathbf{n}^{\mathbf{9}} 1,1957$, São Paulo. Recolhido mais tarde no volume editado po: Egon Schaden, Homem, Cultura e Sociedade no Brasil, 1972, Petrópolis, Ed. Vozes, que reúne trabalhos de vários autores publicados ao longo de muitos anos naquela inestimável revista. 
"Certo índio, vagando pela floresta, notou que no cume de um rochedo alto e escarpado havia um casal de araras no ninho. Resolveu buscar na aldeia quem o ajudasse a tirá-los. No dia seguinte voltou com um rapazinho de nome Botoque, que conseguiu subir por meio de uma escada por eles confeccionada.

"Não têm filhotes, cunhado! Só tem dois ovos", gritou de cima o rapaz.

"Joga-os", mandou o outro.

Mas em vez de ovo, pegou uma pedra, e atirou-a.

"Vai outro!" gritou o rapaz.

E o segundo ovo se transformou também em pedra, como o primeiro, ferindo a mão do índio que estava em baixo"; este, zangado, derrubou a escada e foi embora, não compreendendo que as araias eram encantadas ("oaianga").

Botoque passou muitos dias isolado, sem ver ninguém. Ficou magrinho e com tanta fome e sede que comia os seus próprios excrementos. Afinal, um dia viu passar uma onça pintada, armada de arco e flechas, carregando toda espécie de caças. Quis gritar, mas teve medo.

A onça, vendo no chão a sombra do rapazinho, quis pegá-lo, mas, não podendo, ergueu os olhos e viu, muito em cima, aquele a quem a sombra pertencia. A onça sabia falar, e daí a pouco, o índio estava lhe contando a história.

Tendo consertado a escada, a onça mandou que ele descesse, mas quando Botoque chegou perto, vendo como a onça era grande, teve medo e subiu novamente. Isto fez diversas vezes. Quando, afinal se achava em terra, disse-lhe a onça amiga: "Monta, vamos embora para casa, onde há muita carne assada" $O$ índio não sabia o que significava 'assada", pois naquele tempo só se comia carne crua. Ninguém conhecia o fogo.

Quando chegaram ao covil da onça, Botoque viu um grande tronco de jatobá aceso e fumegando. Viu também, por toda parte, montículos de pedras, do tamanho de cocos babaçú. Eram os primeiros fornos, protótipos do " $k i$ ", hoje usado por todo indio Kayapó. Como o menino achou boa a primeira refeição de carne moqueada!

A mulher da onça, que era uma índia, mostrou logo grande antipatia pelo recém-chegado, ao qual chamava de "me-on-kratum" (o filho alheio ou abandonado). Apesar dos protestos da mulher, a onça, que não tinha filho próprio, resolveu adotá-lo.

Todas as manhãs a onça saía para caçar, deixando o "filho" com a mulher, cuja aversão ao rapaz crescia diariamente. Quando - menino pedia o que comer, ela só lhe dava carne dura e velha, ou embrulhos que pareciam beijús, mas que eram somente fo- 
lhas. Quando ele reclamava, a madrasta lhe arranhava as faces e sobrancelhas, obrigando-o a fugir para mata até que o "pai" voltasse.

A boa onça sempre repreendia a mulher, porém sem conseguir que esta deixasse de maltratar o filho. Um dia, a onça fez um arco novo e algumas flechas, e deu-os de presente a Botoque, ensinando-o a manejá-los. Aconselhou-o também que este atirasse na madrasta, caso esta continuasse a perseguí-lo. $O$ que de fato aconteceu, cravando-lhe uma seta no peito. Amedrontado com o que praticara, resolveu fugir, levando as armas e um pedaço de carne assada em rumo do antigo lar.

Uma escuridão total envolvia a aldeia pois chegou de noite, e só acertou a esteira da mãe dele às apalpadelas. A mãe, que ainda andava triste pela perda do filho, ficou muito espantada. Ajuntando-se todo o povo da aldeia, Botoque contou a sua história e distribuiu carne assada para todos prova-em.

No dia seguinte, os índios foram buscar o fogo. Quando chegaram ao covil da onça, esta, como de costume, já havia saído para a caça. Não acharam vestígios da mulher morta, mas toda a caça do dia anterior estava inteira e crua por não haver quem a moqueasse. Os índios ficaram maravilhados ao ver o fogotratando logo de assar tudo quanto havia de carne.

Eram tantos índios que conseguiram carregar o tronco todo, sem deixar uma brasa sequer naquele lar. Para a onça nada ficou. Unicamente o pássaro azulão apanhou um pedacinho de brasa, graças ao qual aquenta até o dia de hoje o seu ninho.

Como se tornou aleg:e a aldeia desde aquela primeira noite, quando, terminado o "black-out" secular, os índios podiam dançar à luz das fogueiras, apreciar a carne moqueada e, depois, dormir tranquilos à beira do fogo!

Quanto à onça, esta ficou triste e zangada com tudo o que lhe fizera $o$ ingrato filho de criação roubando-lhe tanto o fogo como o segredo de arco e flecha. A onça ficou apenas com o reflexo do fogo nos olhos, que brilham ainda no escuro. Caça com os próprios dentes e come somente carne crua, pois jurou nunca mais comer carne assada. E até hoje odeia a tudo e a todos, especialmente aos que são do gênero humano"

Este mito, ligeiramente resumido, que aparece referido à mesma fonte Banner como "M7: Kayapo-Gorotiré", é mobilizado na imensa sinfonia que é Le Cru et le Cuit (12). No conjunto de 187 mitos indígenas ali examinados, a maioria de origem brasileira mas alastrando-se

(12). - LEVI-STRAUSS, C., Le Cru et le Cuit, 1964, Paris, Plon. 
até o Alasca, há vários que atribuem à onça o papel de senhor-dofogo mas este pode ser também outro animal, como o urubu, ou heróis-civilizadores, divindades ou humanos. No entanto, sugerindo que os mitos estudados não são objetos avulsos mas um encadeamento de que é possível localizar os elos, a importância da relação entre onça e fogo fica sublinhada. Para Levi-Strauss, a onça senhor-do-fogo é típica dos Jê, aparecendo em outros povos indígenas eventualmente ou já submetida a trasformações. Interessa reter suas hipóteses de que o cru se se torna ou cozido por mediação da cultura ou podre por mediação da natureza (13) e de que os mitos Jê e Tupi-Guarani de origem do fogo se colocam "na perspectiva do animal despojado, que é a da natureza", enquanto nos demais a ênfase é dada ao homem despojador. Indica ainda uma distinção entre o conjunto Jê e o conjunto Tupi-Guarani: os Jê consideram o cru e o podre, opostos ao cozido, como uma categoria natural, já os Tupi-Guarani consideram o cru e o cozido, opostos ao podre, como uma categoria cultural.

Fiquem estes delicados deslindes para os antropólogos, que neles são entendidos, mas não se omita a dificuldade instaurada por Guimarães Rosa ao utilizar a língua tupi para expressar coisas que, segundo Lévi-Strauss, são mais tipicamente Jê. Também Gonçalves Dias, no I-Juca Pirama, colocou o tupi na boca dos Timbira, povo Jê (14). O que interessa, no caso presente, e dada a dimensão muito mais ampla que Jê e Tupi-Guarani da questão, é verificar como "Meu tio o iauaretê", longe de ser mera estória de lobisomem ou fábula de licantropia, é uma profunda reflexão sobre natureza e cultura, afinal o tema de toda a impressionante obra-completa de Lévi-Strauss. Trata-se de um texto literário ímpar, como fina percepção do que é a tragédia da extinção de culturas, que ocorreu e ainda ocorre extensamente neste nosso continente americano, do Ártico à Antártida .

Comecemos pelo começo. Por que o título? Iauara, ou jaguar, é onça em tupi, todas as variedades de onça. O cachorro, introduzido pela colonização, vai ter esse nome estendido também a ele. Mas existem várias onças, a parda, a preta, a pintada, e é preciso descobrir qual delas é o tio. Decomposto, o vocábulo dá iauara + etê, ou seja, a onça verdadeira, a onça legítima. O sufixo oposto a-etê é -rana, ou seja, à maneira de, que parece verdadeiro mas não é. Usados com maior intensidade a partir da colonização, os dois sufixos serviram também para indicar o que a ela era ou não anterior. O próprio Guimarães Rosa se serviu dessa distinção ao dar a seu livro o título de

(13) - "O cozimento da carne significa acima de tudo uma vitória sobre a putrefação", já lembrava Bachelard em 1938; cito a tradução portuguesa, A Psicanálise do Fogo, 1972, Lisboa, Ed. Estúdios COR.

(14). - Como notou Matoso Câmara. 
Sagarana, ou seja, à maneira de saga, o que parece uma saga. A chegada dos portugueses trouxe muitas coisas de que o léxico indígena não dá conta, caso em que se dotaram as palavras portuguesas ou se empregaram os dois sufixos distintivos. Assim, por exemplo, os portugueses trouxeram a cana-de-açucar; por isso, uma sanguínea alta, muito comum no país, parecida com a cana-de-açucar, mas que não dá, se submetida aos processamentos tecnológicos, o caldo doce que leva da garapa ao melado, à rapadura, ao açucar e ao alcóol, passou a chamar-se canarana. Isto é, parece cana, mas não é. E a canarana assim se chama até hoje nos dicionários e no falar comum. $\mathrm{O}$ que o índio percebeu imediatamente, Antenor Nascentes confirma: a palavra cana "do skmero-acadiano pelo assírio-babilônio, pelo grego kánna "junco" e pelo latim canna". Cultura estranha, palavra estranha. Já a canarana junta à cana forasteira o sufixo -rana dela diz Antenor Nascentes: "Não pertence à família das Cannaceae e sim à família Gramineae. É alta como a cana-de-açúcar, com que de longe parece". Por um processo análogo, outro exemplo, brancarana designa a mulata tão clara que quase passa por branca, aquela que parece branca verdadeira mas não é (15).

Assim, iauaretê é só a onça verdadeira, não aos nossos olhos, mas aos olhos de quem sabe distingui-las umas das outras. Todavia, o narrador fala em onça, jaguar, cangussu, pintada, pinima, pinima malhalarga, jaguaretê, jaguaretê-pixuna, pixuna, maçaroca, suaçurana, e tigre. A multiplicidade de nomes a um só tempo enriquece o texto, desnorteia o leitor e exibe a intimidade do narrador com a natureza. Aqui, Von Ihering pode dar uma ajuda (16): todas pertencem a uma só família, a dos Felídeos; e onça ou jaguaretê (é a tradicional onça pintada das fotografias, desenhos e zoológicos), também impropriamente chamada tigre. Von Ihering, que a classifica como Felis onsa, registra que, embora os especialistas não possam dizer se se trata de subespécies, os caçadores distinguem mais duas variantes, afora a principal, que é de cor amarelo-ruiva e corpo coberto de rosetas pretas nos lados, dispostas em cinco séries, enquanto na cara e nas extremidades as manchas são de vários tamanhos e a cauda tem anéis pretos e ponta também preta. Essas duas outras variantes são a canguçu (em tıpi $=$ cabeça grande), que é um pouco menor mas se destaca pela cabeça mais volumosa, enquanto as manchas são menores e mais numerosas;

(15). - Nestas distinções, bem como em outras dificuldades ao longo do trabalho, pude contar com o saber e a paciência de Carlos Drummond, Professor Titular da Área de Línguas Indígenas na FFLCH - USP.

(16) . - VON IHERING, Rodolpho, Dicionário dos Animais do Brasil, 1940, São Paulo, Edição Secretaria da Agricultura, Indústria e Comércio do Estado de São Paulo. 
e a onça preta (preto = pixuna, em tupi), que é escura, quase preta, mal sendo possivel distinguir o contorno das rosetas.

Então, jaguaretê, a onça verdadeira, a onça legítima, é tanto a pinima (pintada = pinima, em tupi), como a pixuna, a canguçu, o tigre, a onça e o jaguar. Resta a questão da maçaroca e da suaçurana, que não pertencem ao parentesco do narrador: "Mas suaçurana não é meu parente, parente meu é a onça preta e a pintada. "Essa afirmação implica dois elementos: primeiro, a distinção de exclusão; segundo, suaçurana é -rana, não é -etê, ou seja, parece onça mas não é a onça legítima e verdadeira, que todas as outras são. Acrescente-se a informação do texto de que a suaçurana é medrosa, até abandona os filhotes na fuga. Novo recurso a Von Ihering esclarece. A sussuarana, que é como ele grafa a palavra, assim como Guimarães Rosa grafa cangussu em vez de canguçu, também é da família dos Felídeos, mas de espécie diferente, Felis concolor, onça parda ou onça vermelha. O nome que lhe dão norte-americanos e europeus é puma; os caçadores distinguem variedades como a de lombo preto e a ruiva, bem como a maçaroca (pelo crespo, em tupi).

As repetidas afirmações do narrador de que é parente de onça, de que o iauaretê é seu tio, se resolvem na declaração de identidade: "Mas eu sou onça. Jaguaretê tio meu, irmão de minha mãe, tutira .

Ou, sendo tutira em tupi o tio irmão da mãe, as afirmações apontam para um parentesco classificatório matrilinear, onde, no nosso código, os tios irmãos da mãe são pais, mas no código do narrador os pais são tios. Assim, "meu tio o iauaretê" ao mesmo tempo indica filiação (isto é, sou filho de onça e não filho de gente) e origem indígena tribal. Por outras palavras, meu pai pode ou não ser meu pai, já que pertenço ao clã tribal de minha mãe; mas meu pai é com certeza o irmão de minha mãe: todos os irmãos do sexo masculino de minha mãe (para nós, tios) são meus pais. No universo do discurso do narrador, o irmão de sua mãe é seu pai. Traduzido para o português, o sintagma que indica esse grau de parentesco é meu tio. Um passo adiante: traduzindo de um universo de discurso para outro, o nosso, o título "Meu tio o iauaretê", sintética e admiravelmente, propõe o branco, o índio e a onça misturados, tal como no texto se misturam o português, o tupi e o animal dos resmungos e rugidos. Ao mesmo tempo, afirma: não pertenço à raça brança de meu pai, pertenço ao clã tribal de minha mãe, cujo totem é a onça. A onça, sendo o totem do clã tribal de minha mãe, é meu ancestral, meu antepassado, minha origem; e a ele regresso, à onça, defraudado senhor-do-fogo.

Situado na linha de demarcação entre natureza e cultura, o fogo assinala o momento em que o homem deixa de comer carne crua, submetendo-a ao fogo antes de ingeri-la e assim se distinguindo dos de- 
mais animais carnívoros. Ao mesmo tempo, o fogo é arma de defesa e ataque, dando superioridade ao homem sobre os outros seres vivos. As duas faces do fogo, a benéfica e criadora, e a maléfica e destruido$\mathrm{ra}$, aparecem conjuntamente; o fogo protege, defende, cria, mas também mata e destrói.

Não é por acaso e simploriamente, portanto, que na mente do homem a descoberta do uso do fogo tenha ficado marcada por um grave senso de responsabilidade. Tão radicalmente é um salto no rumo de civilização, abrindo definitivo abismo entre o homem e seus demais irmãos os animais, que em todas as culturas a descoberta do fogo se apresenta registrada e mmitos. Essa descoberta raramente é tranquilizadora e apenas motivo de regozijo; quase sempre se acompanha da idéia de roubo. Ninguém dá de presente ao homem o fogo; é preciso roubá-lo, o que representa uma ousadia e um sacrilégio, colocando o homem na expectativa de ser por isso punido.

Sabemos, é claro, ao nível de nosso saber positivista, que o fogo não precisa ser roubado a seres míticos. $O$ fogo existe na natureza: a árvore atingida pelo raio se incendeia, tornando-se chamas e brasas, pedras que rolam entram em atrito despedindo faíscas que ateiam fogo ao capim seco. Basta conservá-lo, a partir daí, evitando que se extinga. Mas, mesmo nesse caso, ele foi roubado à natureza. Só a nature$\mathrm{za}$, esse conjunto de forças misteriosas, detem o direito do uso do fogo; se o homem se apropria desse uso, está roubando alguma coisa superior a suas próprias forças.

Em culturas ilustres que estão na origem da nossa, como a grega, a descoberta do uso do fogo aparece como um roubo aos deuses. Foi Prometeu quem violou o monopólio dos deuses e roubou o fogo para dá-lo aos homens. Sofreu castigo terrível; acorrentado a um rochedo ou coluna, a águia de Zeus vinha diariamente roer-lhe o fígado que diariamente se regenerava para renovação do suplício.

O mito de Prometeu estréia na Teogonia de Hesíodo, por volta do século XIII A.C., primeira conhecida tentativa de sistematização dos mitos gregos pré-existentes ao poema. No outro texto do poeta, Os Trabalhos e os Dias, é narrada a vingança tomada por Zeus contra os beneficiários do roubo, no mito de Pandora. Precedida pelas olímpicas gargalhadas de Zeus, modelada em barro, ornada de prendas e malícias, depois animada, Pandora traz aos mortais todos os males do mundo. Não só o semidivino ladrão foi castigado, como também toda a espécie humana. Esses dois mitos iniciais permeiam a cultura grega e latina, renitentemente, em inúmeras versões.

$\mathrm{Na}$ outra fonte de nossa cultura, que é a hebraica, o fogo aparece como atributo de Jeová. No Gênesis, Adão e Eva são expulsos do 
jardim do Eden por terem comido do fruto da árvore do bem e do mal; perdem a inocência e a capacidade de viver como irmãos entre os animais, aos quais Adão dava a cada um o nome. Expulsos, Jeová "pôs querubins ao oriente do jardim do Eden, e uma espada de fogo que andava ao redor", para impedir a volta.

Como todo grande deus, Jeová conserva o monopólio do fogo. De dentro de uma sarça ardente, que estava em chamas mas não se consumia, fala a Moisés e lhe confere a missão de retirar o povo eleito da servidão no Egito. Uma das sete pragas que afligem o país do recalcitrante Faraó é a praga da saraiva, na qual granizo e fogo do céu corriam pela terra e tudo queimavam. E, na caminhada pelo deserto em busca da Terra Prometida, Jeová guiava seu povo em forma de coluna de nuvens durante o dia e de coluna de fogo durante a noite. Nas ordenações da liturgia, os sacrifícios propiciatórios ou expiatórios constam sempre de holocaustos, seja de animais, seja de cereais ou outros manjares; e o fogo do altar do holocausto deve ser perpétuo: "O fogo arderá continuamente sobre o altar; não se apagará" É o fogo do Senhor, e não dos homens, que queima os holocaustos, como sinal do favor divino, sinal de que aceita o sacrifício. E de tal maneira o Senhor é cioso do fogo sagrado, que os dois filhos de Aarão, Nadab e Abiú, caem mortos instantaneamente quando ateiam fogo eles mesmos em seus incensórios. Porque "trouxeram fog oestranho perante a face do Senhor" foram consumidos pelo fogo que saiu do altar do Senhor. Lavrando o descontentamento entre os seguidores de Moisés, cansados de vagar pelo deserto sem chegar à Terra Prometida, o episódio se repete mais tarde, desta vez com duzentas e cinquenta pessoas murmuradoras trazendo seus incensórios já acesos e sendo queimadas pelas labaredas que se projetam do altar e os envolvem. Continuando a murmuração, já que agora eram muita sas mortes pelas quais Moisés era responsabilizado, Jeová repete a ameaça e os fiéis descontentes começam a morrer. Só a intervenção de Moisés, que manda Aarão acender seu incensório com fogo do altar e fazer expiação pelo povo, faz cessar a praga. Mas a essa altura já eram catorze mil e setecentos os mortos.

Assim como no Velho Testamento Sodoma e Gomorra são destruídas devido a suas abominações pelo fogo do céu, que os diferentes profetas também invocam, igualmente no Novo Testamento o Apocalipse promete um juízo final flamejante, quando se juntarão o fogo que vem do alto e o fogo que sobe do abismo.

Em culturas consideradas menos ilustres e gioriosas, mas que também são fonte da nossa, apesar de sua continuidade ter sido cortada pelas contingências da invasão, da escravização e da extinção, os mitos do roubo do fogo são igualmente importantes. Disso soube se 
valer o invasor, em forte produção ideológica de superioridade para com o invadido, que fez parte do processo. O pobre foguinho do índio, tão difícil de ser aceso por friç̧ão e conservado, sob a ameaça de terríveis perigos de escuridão e desconforto, foi deslumbrado pelo poderio de fogo do invasor. São muitas as narrativas, lendárias ou não, que restaram do terror sagrado com que os índios se rendiam ao novo senhor-do-fogo: Caramuru disparando sua arma, Anhanguera ateando chamas à aguardente esparzida .

O conto de Guimarães Rosa, colocando-se decididamente do lado de lá, mostra a penosa tentativa do índio - perdidos seus valores, sua identidade, sua cultura - de abandonar o domínio do cozido e voltar ao domínio do cru. Se antes se destacara como bom caçador de onças com armas de fogo, depois abandona-as para se servir da zagaia, arma por assim dizer crua. Se antes comia comida cozida, depois passa a comer comida crua. Se antes matava onças, depois passa a matar homens. Se antes servira ao branco senhor-do-fogo, depois passa a servir à onça senhor-do-fogo.

$\mathrm{Na}$ fala que sai inicialmente desarticulada e sonsa, as revelações só se farão muito lentamente, sob o progressivo afrouxamento da censura provocada pela ingestão cada vez maior da cachaça. Sua filiação afirma a identificação com a mãe e não com o pai. A mãe era "gentio Tacunapéua", que é, ou era, uma tribo tupi assentada às margens do Iriri, um afluente do Xingu. Se a mãe era "boa, bonita, me dava comida, me dava de-comer muito bom, muito, montão", com o pai a relação é diversa. "Meu pai era bugre índio não, meu pai era homem branco, branco feito mecê, meu pai Chico Pedro, mimbauamanhanaçara (17), vaqueiro desses, homem muito bruto. Morreu no TungoTungo, nos gerais de Goiás, fazenda da Cachoeira Brava. Mataram. Sei dele não. Pai de todo o mundo. Homem burro" Com a mãe aprende muitas coisas. Que é parente de onça, por exemplo. Ela lhe conta histórias de seu povo, mostra-lhe as quatro estrelinhas do Sejuçu (as Plêiade ou Setestrelo) e lhe diz que a que está faltando é ele. concepção corrente na mitologia indígena, essa de tornar-se estrela quando morrer. Também lhe ensina o valor da liberdade e o medo da prisão. E afinal era tão boa para ele quanto uma onça para seus filhotes. A oposição se instaura também entre animal selvagem materno e animal doméstico paterno.

Nesse trançado, a primeira resultante é a perda de identidade. Não sabe mais o que é, não sabe quem é, não sabe mais seu nome. "Ah!, eu tenho todo nome. Nome meu minha mãe pôs: Bacuriquire- 
pa. Breó, Beró (18) também. Pai meu me levou pra o missionário. Batizou, batizou. Nome de Tonico; bonito, será? Antonho de Eiesús.

Depois me chamavam de Macuncôzo, nome era de um sítio que era de outro dono, é - um sítio que chamam de Macuncôzo. Agora, tenho nome nenhum não, não careço. Nhô Nhuão Guede me chamava de Tonho Tigreiro. Nhô Nhuão Guede me trouxe pr'aqui, eu nhum, sozim. Não devia! Agora tenho nome mais não.

Também surge, aos retalhos, fisgados aqui e lá, o antecedente de nomadismo e falta de raízes. Nascido gentio Tacunapéua, isso foi muito longe; depois morou com índios Caraó, o Krahó ou Kararaô dos mapas de localização indianistas, tribo Jê e não Tupi; depois morou num lugar chamado Socó Boi de onde teve que sair porque não quis participar de assassínios a soldo e foi considerado covarde; depois foi esbarrar na Chapada Nova; depois não o aceitaram como trabalhador na roça, por ser incompetente; depois Nhô Nhuão Guede o enviou para aquele fim de mundo para matar onças, no que era perito. Entremeados, os lapsos não preenchidos .

Progressivamente rejeitado, regressivamente rejeitando. Não sabia trabalhar. Matar homens como homem, em tocaias e por encomenda, recusara-se a fazer. Matar onças como homem, isso fazia, ininialmente cJm arma de fogo, como um branco, depois só com zagaia, como um índio. Daí a matar homens, não com armas de branco nem de índio, mas como onça, basta um passo. Antes disso, um rrito de passagem: comer carne de onça e esfregar-se com seu unto. "Carne dela eu comi. Boa, mais gostosa, mais macia. Cozinhei com jembê de caruru bravo. Muito sal, pimenta forte. Da pinima eu comia só o coração delas, mixiri (19), comi sapecado ,moqueado, de todo o jeito. E esfregava meu corpo todo com a banha. Pra eu nunca eu não ter medo!" (20)

A transformação é quase repentina, e numa rápida sequiência o sobrinho-do-iauaretê elimina todas as pessoas da região. Primeiro é o preto Bijibo, com quem ele viaja junto, quando voltava de ter "ido falar brabo com Nhô Nhuão Guede, que eu não ia matar onça nenhuma mais não" Gostava do preto, mas desprezava-o por sua covardia e porque cozinhava e comia o tempo todo. Lembro que a preferência de onça por carne de preto, na crendice popular, é mencionada por muitos autores, inclusive por Von Ihering. O preto Bijibo, ele não mata pessoalmente, mas leva para onça comer. Em seguida, chegando a

(18). - f. Peró $=$ português, branco, aplicado pelos índios em língua geral ao invasor; aqui, indica uma acentuação despreziva da pa:te branca paterna.

(19). - Em tupi = frito e conservado em gordura.

(20). - Essa prática é referida também no Grande Sertão: Veredas. 
seu rancho, encontra outro, o preto Tiodor, ajustado pelo mesmo patrão para substitui-lo; mas esse não morrerá já. Agora é a vez de Seo Riopôro, geralista, que sem maiores motivos xinga-o e xinga-lhe a mãe; esse também é levado para onça comer: "Matei, eu matei? A 'pois, matei não. Ele inda tava vivo, quando caiu lá em baixo, quando onça Porreteira começou a comer "O próximo é o jababora (21) Gugué, que não fazia nada, passava o dia todo na rede, pedia-lhe para trazer água; mais um que onça ganha de presente. Depois é Antunias, também jababora, avarento, comia e escondia a comida dos outros, manda buscar lenha para o fogo e consertar uma alpercata; tem o mesmo destino dos anteriores. Agora é a vez de Maria Quirinéia e seu marido doido acorrentado; foi lá para beber café, ela lhe deu café, deu comida e tentou seduzi-lo. É a primeira que ela quase mata; mas na hora em que ia apertar-lhe o pescoço, ela fala bem da mãe dele. $O$ sobrinho-do-iauaretê, então, desiste, aconselha-a a mudar-se dali porque as onças estão comendo todo mundo e, tão avesso ao trabalho, carrega-lhe a mudança e conduz seu marido pacientemente.

Doravante, a tarefa é pessoalmente sua. Seu Rauremiro, homem prepotente, humilhava-o, não o deixava entrar na casa, chamava-o assobiando como se fosse um cachorro; é verdade que lhe dava comida, mas ele a recusava. Sente um grande frio, perde a consciência e quando volta a si o veredeiro Rauremiro com toda a família, mulher, filhas, filho, estão mortos e ele coberto de sangue, com sangue na boca. $O$ último é o preto Tiodoro, meio gordo, que não sabia caçar onças mas queria vender os couros, que pretendia que ele fosse buscar lenha e água. Preto Tiodoro, apavorado, chega a vê-lo vindo de quatro pelo chão. Era o único sobrevivente em toda aquela zona.

É nesse momento que o narrador conclui seu relato, tentando convencer o interlocutor a deixá-lo encostar-lhe a mão, declarando que está com muito frio e que está de quatro sem qualquer motivo. Seguem-se exclamações e os rugidos e gemidos da agonia. Em suma: sua missão inicial de desonçar a região transformou-se, e ele a executou até o fim, em missão de desgentar a região.

Retomando alguns fios soltos, podem-se observar três invariantes no que diz respeito a todas essas pessoas. Primeira: o autor das mortes não tinha raiva de ninguem, achava todos muito bonzinhos, depois até ficava com pena. Segunda: todas tinham graves defeitos, do ponto de vista cristão equivalentes aos sete pecados capitais. Pense-se no medo e na gula do Preto Bijibo, na soberba e ira de Seo Riopôro e Seu Rauremiro, na preguiça de Gugué, na avareza de Antunias, na luxúria de Maria Puirinéa e do Preto Tiodoro, aliada no caso deste ainda a

(21). - Em tupi $=$ criminoso, fugitivo. 
medo e avareza. Terceira: todas as pessoas tinham alguma relação com comida e com trabalho, acentuada pelo texto. As três invariantes combinam sabiamente o animal, o branco e o índio, como veremos a seguir.

A primeira, o matar sem ódio, está ligada à opção de ser onça . Ao contrário dos homens, onça mata para comer, só fica brava na hora de matar: "onça pensa só uma coisa - é que tá tudo bonito, bom, bonito, bom, sem esbarrar. ( . . ) Quando alguma coisa ruim acontece, então de repente ela ringe, urra, fica com raiva, mas nem que não pensa nada: nessa horinha mesma ela esbarra de pensar. Daí, só quando tudo tornou a ficar quieto outra vez é que ela torna a pensar igual, feito em antes.

A segunda invariante seleciona os aspectos cristãos dos sete pecados capitais para justificar as mortes. E a terceira, mais relevante para o argumento, mostra aquelas pessoas ou comendo, ou dando comida ou a recusando, ou providenciando lenha e água para cozinhar. Elas encarnam assim o inimigo - o domínio do cozido - que ele está em vias de renegar. Quanto ao trabalho, ou as pessoas estão trabalhando ou, o que é mais comum, estão querendo forçá-lo a trabalhar para elas. Ora, esse pode ser um valor da ética do branco, jamais do índio nem da onça. Não é para eles o que Georges Bataille chamou de "o mundo prosaico da atividade", em $A$ Literatura e o Mal. Mais forte, como Seo Riopôro que o chama de senvergonha e mentiroso e ainda lhe xinga a mãe, tudo sem qualquer motivo, ou Seo Rauremiro que não permite sua entrada e o chama por assobio; ou mais atenuada, como a preguiça de Gugué, que não sai da rede mas o manda fazer coisas, ou Maria Quirinéia que o quer para objeto de seu prazer, é sempre a prepotência do outro que entende usá-lo

A combinação das três invariantes mostra como são justos, lógicos e necessários os assassínios, no contexto e nos valores do contexto.

Das mais belas sequências do conto é aquela que entra na intimidade do convívio com as onças. Cada onça é um indivíduo, com traços físicos imediatamente identificáveis, manias, preferências, caráter; o sobrinho, qual Adão nomeador, entre elas vive. São Mopoca, canguçu fêmea, a mandona Maramonhangara, Tatacica pegadora de peixe, Uinhúa, Porreteira malha-larga e enorme, a Rapa-Rapa velha e esperta, Mpú, Nhã-ãí Tibitaba, Coma Piranga, Putuca, muitos machos como o Papa-Gente, Puxuêra, Suú-Suú que gosta da onça Mopoca, Apiponga bom caçador, Petecaçara que enlouqueceu, os dois irmãos Uitauêra e Uatauêra. Os nomes tupis, tais como os poucos do léxico português, guardam referências aos traços físicos ou de comportamento de cada uma. Dentre todas, uma é especial, a primeira que ele não 
matou, a primeira com quem ele conversou e que com ele conversou em lvngua de onça, a canguçu Maria-Maria, sua amada. Assim ele a descreve: "Bonita mais do que alguma mulher. Ela cheira à flor de pau-d'alho na chuva. Ela não é grande demais não. É cangussu, cabeçudinha, afora as pintas ela é amarela, clara, clara. 8empo da sêca, elas inda tão mais claras. Pele que brilha, macia, macia. Pintas, que nenhuma não é preta mesmo preta, não: vermelho escuronas, assim ruivo roxeado. Tem não? Tem de tudo. Mecê já comparou as pintas e argolas delas? Cê conta, pra ver: varêia tanto, que duas mesmo iguais cê não acha, não. Maria-Maria tem montão de pinta miúda. Cara mascarada, pequetita, bonita, toda sarapintada, assim, assim. Uma pintinha em cada canto da bôca, outras atrás das orelhinhas. . Dentro das orelhas, é branquinho, algodão espuxado. Barriga também. Barriga e por debaixo do pescoço, e no por de dentro das pernas. Eu posfazer festa, tempão, ela aprecêia. "O alto teor erótico da descrição de Maria-Maria é confirmado por algumas observações indicadoras de que ela é seu par mefinino, como por exemplo a afırmação de que ela matará qualquer macho que a ela se apresente apesar de ser seu parente, e a de que ela nunca mais terá tilhotes.

"Aqui, roda a roda, só te meu e onça. O resto é comida para nós.": regressando do cozido, para o cru, o sobrinho-do-iauaretë se reconheceu nas onças e fol por elas reconhecido. Daí, o remorso permanente, volta e meia reaparecendo entremeado em sua fala, devido ao tato de ter matado tantas onças antes da identıticação.

Chama a atenção de seu interlocutor repetidas vezes para que nunca mencione esse assunto, que só ele mesmo tem o direito de trazêlo à baila. Numa dessas vezes, indica o grande número de onças que já matou, em conta feita à maneira indígena: "Matei, montão. Cê sabe contar- Conta quatro, dez vezes, tá í: esse monte mecê bota quatro vezes." O tema é delicado e envolve do fundo da memória aquilo que foi reprimido. Contrastando, não há remorso com relação aos seres humanos que ele matou. Se no começo do relato repete que os moradores da região morreram de doença, é por prudência; pergunta ao interlocutor se por acaso é soldado, pois a mãe o ensinara a ter medo de soldado e ele não suportaria ser preso. Com o destravar da língua pela cochaça, já no fim do relato, acaba contando que foi ele quem matou. Quanto às onças, dá-se o inverso. Começa contando que matou muitas, e só bem depois confessa seu amor por elas.

Sentir-se culpado por ter matado onças e não sentir-se culpado por ter matado pessoas, mesmo que reconheçamos que as onças são 
muito melhores que as pessoas, vai encontrar sua explicação nas análises clássicas de Frazer e de Freud. O sobrinho-do-iauaretê reconheceu na onça seu ancestral, seu antepassado mítico, seu totem. Ora, o totem é o único ser vivo que não se pode matar, a não ser por ocasãa do repasto totêmico. Nesse evento ritual, o totem é abatido coletivamente, ao mesmo tempo pranteado e festejado, para depois ser comido por todos os participantes. Na reconstituição freudiana, o repasto totêmico é a representação sagrada do primeiro crime da humanidade, aquele que permitiu ao homem dar o primeiro passo no rumo da civilização, o assassínio do macho chefe da horda primeva por seus filhos. Aparece com clareza nas teogonias gregas, onde cada deus supremo cuidava de matar todos os seus filhos para não ser por eles destronado; mas sempre algum escapava e de fato matava o deus-pai. Assim ocorreu com Cronos, depois com Uranos, e só a partir de Zeus se interrompe a tradição. Na horda imaginado, o macho chefe detinha o monopólio das mulheres e do poder; a união dos filhos, que permitiu enfrentar, matar e comer o pai, para absorver suas qualidades excepcionais, instaurou a culpa. Sucessivamente, como passos para formas sociais cada vez mais complexas, o sacrificado foi sendo substituído. Primeiro fo: abatido o chefe da horda, do qual dependia a ordem cósmi$\mathrm{ca}$, a fertilidade da terra, dos animais, das mulheres; depois, outra pessoa em seu lugar, pessoa que era sagrada e encarnava o deus; depois um animal; depois efígies e simulacros. Cada passo - e a aceitação dessa teoria depende de infindáveis discussões a respeito da relação de precedência entre o mito e o rito - representaria um avanço na civilização. Na forma mais moderna e mais simbólica, a Eucaristia, a distribuição do pão e do vinho, vem acompanhada pela fórmula ritual: "Tomai e comei. Este é meu corpo e este é meu sangue."

Ora, o pobre sobrinho-do-iauaretê matou inúmeras vezes seu totem, sozinho. Refere constantemente seu estado de absoluta solidão, decorrente não da falta de companhia, pois tem a de que gosta, a das onças, mas do peso da culpa que carrega, enquanto índio, por ter individual e não ritualmente matado muitas vezes seu totem. E como se tivesse matado sua raça, seu povo, sua gente, seu pai. Na perplexidade da confusão de culturas, destribalizado, não tinha chegado a compreender claramente o que a mãe lhe dizia na infância sobre o parentesco com o jaguaretê. Tenta por isso esquecer essa parte do passado, mais precisamente jogá-la fora: "Hui! Atiê! Atimbora! Mecê não pode falar que eu matei onça, pode não. mu, posso. Não fala, não. Eu não mato mais onça, mato não. E feio - que eu matei. Onça meu parente. Matei, montão. ( ) Cada que matei, ponhei uma pedrinha na cabeça. Cabaça não cabe nem outra pedrinha. Agora vou jogar cabaça cheia de pedrinhas dentro do rio. Quero ter matado onça não. Se mecê falar que eu matei onça, fico brabo. Fala que eu não matei, 
não, tá-há? Falou? A-é, ã-ã. Bom, bonito, de verdade. Mecê meu amigo!" A solução que encontrou para o impasse da confusão de culturas foi dentificar-se com as onças. Recusando o código do branco e perdendo o código do índio, entende ao pé da letra os ensinamentos da mãc, de que "é onça"; não pode mais entender a diferença entre ser onça e ter a onça como ancestral mítico, animal tabu com quem as relações são cuidadosamente reguladas. Transformado em onça e vivendo maritalmente com uma onça, ainda outra armadilha o aguarda, e o texto é altamente sugestivo nesse sentido. Sua mãe índia se chamava Mr'Iara Maria; decomposto, em tupi e português, pode ser lido como Senhora Maria Maria ou Dona Maria Maria; mesmo sem tradução, é perfeitamente legível o nome Maria-ra-Maria. Sua companheira onça se chama Maria-Maria. Ao sacrilégio de ter matado o totem vem-se somar o sacrilégio do incesto. Violou ao mesmo tempo os dois tabus fundantes da civilização, na desorganização de quem está perdido entre várias culturas. Branco ele não é e nem deseja ser. Também não pode ser índio, porque ao rejeitar o branco prepotente e comedor de comida cozida rejeitou o homem. Tampouco pode ser onça, porque, ao tentar sê-lo, carrega a culpa de duas violações de tabu. Exemplarmente, termina abatido a tiros de revólver pelo interlocutor branco.

A antiquíssima proibição bíblica de ingerir sangue, porque este é privilégio de Jeová e "a alma da carne", se combina neste texto com o elemento fogo e o elemento álcool. Já Northrop Frye observou como são comuns "os vínculos entre o fogo, o vinho embriagador e o sangue quente e rubro dos animais" (22). Ao tentar tranquilizar o interlocutor e fazê-lo adormecer, o sobrinho-do-iauaretê deixa escapar uma revelação precoce: "Hum, hum, fico bêbado não. Fico bêbado só quando eu bebo muito, muito sangue. "Tentando passar para o lado de cá do fogo e voltar para o cru, o que perde o narrador é a cachaça que the desemperra a língua e o revólver - arma de fogo que lhe tira a vida. A associação entre o fogo e o álcool, já feita por Bachelard n'A Psicanálise do Fogo, mostra a ligação da bebida alcoólica não com o líquido, mas com outro dos quatro elementos cosmológicos que é o fogo: "Dentre todas as matérias do mundo, nenhuma como a aguardente se encontra tão perto da matéria do fogo." Ao nível do mero código linguístico no noss ocaso a associação é dada no vocábulo aguardente; e "ficar de fogo" ou "pegar um fogo" é embriagar-se. No texto que nos ocupa, a associação é reiterada. Já no primeiro parágrafo, o caçador extraviado encontra o rancho devido ao fogo: "Mecê enxergou êste foguinho meu, de longe?" E a oferta de

(22). - FRYE, Northor, Anatomia da Crítica, 1973, São Paulo, Ed. Cultrix. 
cachaça que ele faz, a cachaça tecnológica do cozido e não do cru, é logo aceita: "Sei fazer, eu faço: faço de cajú, de fruta do mato, do milho. Mas não é bom, não. Tem esse fopo bom-bonito não. Dá muito trabalho. Tenho dela hoje não. Tenho nenhum. Mecê não gosta. E rachaça suja, de pobre. "Na crença popular, que Von Iherinv menciona, os animais carnívoros se embriavam com o sangue, que bebem primeiro até ficarem bêbados, e só mais tarde é que comem a carne. E o que costuma se passar com as onças do conto e com o próprio narrador, que ademais até contagia seu gosto em matéria de cores: "Eu, eu gosto de vermelho!" O álcool, o sangue e o fogo formam um esquema, neste conto, formam um esquema de perdição para o narrador.

Não conseguira desvincular-se totalmente de sua condição de homem e portanto do fogo. Dele se utilizava, por exemplo, para pitar e para ameaçar: "Ixe, quando eu mudar embora daqui, toco fogo em rancho: pra ninguém mais poder não morar Ninguém mora em riba do meu cheiro. "Também o menino-lobo Mowgli, no Livro da Jângal de Kipling, assim procede. Vivia entre os animais e deles se considerava um igual, não tendo a menor noção de que era u mser humano. Mas ao ter sua sobrevivência ameaçada por alguns deles vai a uma aldeia e rouba um pouco de fogo, a flor-vermelha que aterroriza os outros animais e lhe dá a vitória sobre eles. Nosso narrador sabe muito bem qual é sua opção, pelo cru, não pelo cozido, nem pelo podre: "Eu como carne pôdre não, axe! Onça também come não." Mas não conseguira ficar inteiramente no domínio do cru. Por isso, pelo fogo de seu rancho foi encontrado pelo fogo da cachaça foi revelado; pelo fogo do revólver foi destruído. Esse passo definitivo, esse cruzar da linha divisória, sem volta, do cozido para o cru, esse retôrno impossível, será sua perdição.

Não se pode examinar um conto como esse sem render homenagem ao autor. A proeza, do ponto de vista linguíistico, repousa na chance certeira que apanha o fenômeno da reduplicação tupi e faz dela o eixo central da composição. Segundo o Pe. Lemos Barbosa (23), a reduplicação, ou repetir a mesma palavra duas vezes, funciona como intensificador, seja para indicar plural, superlativo ou duração. Em muitos casos ela exige elipses de afixos; e, se no presente texto quase tudo vem duas vezes, pode vir duas vezes em tupi, ou duas vezes em português, ou uma em tupi e outra em português. $O$ que facilita muito a compreensão do texto, recurso hábil para dar-lhe efeito de estranhamento mantendo todavia a possibilidade de comunicação, é

(23). - BARBOSA, R. Lemos, Curso de Tupi Antigo, 1956, Rio, Livraria São José, especialmente Lição $50^{a}$. 
reduplicar o vocábulo tupi em português. Sempre que ocorre o tupi, sua "tradução" vem contígua ou próxima. O caso mais marcante é certamente o de uma dupla reduplicação, devido a sua recorrência que fica fazendo ponteio no texto. Refiro-me ao "porã-poranga, bom-piloto" Em tupi, tal como no grego calós, poranga tanto pode significar bom como bonito, mesmo que exista também catu para belo. Para a reduplicação, daí o sufixo monossilábico; é do Pae. Lemos Barbosa o exemplo, também adjetival, de pinima-pintado, e pini-pinima $=$ todo pintado, muito pintado, cheio de pintas. No correspondente português, bom e bonito, o sufixo da primeira palavra cai para a reduplicação, transformando-os, tal como no tupi, numa só categoria lógica. Estamos lidando com um homem-onça, índio-branco, bilingüe; e com um grande escritor.

E preciso lembrar a sensibilidade que cria diante de nossos olhos o problema vivo do índio-em-geral num índio só, que é seu personagem. A sensibilidade para comungar com a natureza, com as plantas, com as onças, com cada pequeno ruído ou sinal, que o sobrinho-doiauaretê vai interpretando para seu hóspede sem sair do rancho. E também o extraordinário feito que é realizar tudo isso num só fala. O notável observador de pessoas e de animais que se destaca em todas as suas obras lembra os cinco textos sobre jardins zoológicos que figuram no Ave, Palavra (2.). Ali, dispensando a mediação da ficção, o autor estende suas sensibilíssimas antenas e fica tentando apreender cada bicho e construir um equivalente em palavras. Outros textos do mesmo livro lidam muito diretamente com animais, como "quemadmodum, "As garças", um e outro "Aquário", "Ao Pantanal" Outros são do mesmo modo dedicados aos homens de sua terra, seja os vaqueiros de "Pé-duro, chapéu-de-couro", seja os japoneses hortelãos de "Cipango", seja, especialmente, "Uns índios (sua fala)" Nesse texto, Guimarães Rosa se coloca como alguém que está anotando palavras de um Tereno que encontrou em Mato Grosso, interessado em suas pessoas e em sua linguagem: "Respeitei-a, pronto respeitei seus falantes, wuno se representassem alguma cultura velhíssima." E desapontad. ao desistir de comprovar, por falta de informação, uma linda hipótese: a de que, em língua tereno, azul seria "sangue de céu", verde seria "sangue de folha", e por aí afora.

Em sua obra, bastante desigual, sempre achei um mistério que uma óbvia obra-prima, como "Meu tio o iauaretê", tivesse ficado tanto tempo por ele mesmo relegada. Publicada pela primeira vez na revista Senhor, de n. ${ }^{\circ} 25$, em março de 1961, não foi incluída pelo autor em seus dois livros seguintes, Primeiras Estórias e Tutaméia-Terceiras

(24). - GUIMARĀES ROSA, João, "Meu tio o iauaretê", em Estas Estórias, 1969, Rio, José Olympio. 
Estórias. Acabou saindo postumamente, mas em edição preparada pelo autor, em Estas Estórias, (25), onde o desnível de qualidade com relação aos demais textos do conjunto é gritante. Em nota introdutória, Paulo Rónai registra que no original datilografado consta uma anotação do autor afirmando que o conto é anterior a Grande Sertão:

Seria a exploração de um mesmo achado formal a explicação para o engavetamento? $O$ brilhante feito de conseguir pôr uma fala que flui ininterruptamente da boca de um narrador, que é o outro? De fato, tanto o conto como o longo romance saem em forma de fala emitida por um narrador-personagem, autobiografando-se. Em ambos os casos, o narrador-personagem tem sua alteridade marcada com reloção ao interlocutor que é homem da cidade e portador de signos da urbanidade, nem sertanejo num caso, nem meio-índio no outro. Evitando o contraste de discursos, o interlocutor nunca fala, mas é colocado na fala do outro por meio de interpelações e respostas a hipotéticas perguntas. Assim, a fala do narrador-personagem só indiretamente se dirige ao leitor, apesar de, em ambos os casos, ser um monólogo direto iniciado por um travessão: seu alvo é o interlocutor presente na situação criada, e só dali ela inflete na direção do leitor. Este, evidentemente, está colocado para cá do interlocutor, e recebe pela mediação deste o monólogo a ele destinado.

Ainda mais, nos dois casos o narrador é filho sem pai, que guarda boa lembrança da mãe que o criou. Em duas passagens, é a menção inesperada à bondade da mãe que desfaz a raiva do narrador contra alguma outra personagem com quem ele está contando seu contacto, Diadorim no romance, Maria Quirinéia no conto. Se no conto o narrador é agregado do fazendeiro Nhô Nhuão Guede (Nhuão = João, em pronúncia tupi), no romance era agregado do fazendeiro Jidião Guedes. Teriam estas coincidências sido observadas pelo autor, que não queria repetir-se?

Tudo isso, todavia, importa menos que a beleza da realização e a vertigem da intuição; pode ser que isso mesmo o amedrontasse. No meneionado texto sobre os Terenos, estreado em jornal em 1954, lá diz ele: "Toda língua são rastros de velho mistério." pio.

(25) - GUIMARÃES ROSA, João, Ave, Palavra, 1970, Rio, José Olym- 